\title{
TROPICAL PALMS AND ARUMS AT NEAR-POLAR LATITUDES: FOSSIL POLLEN EVIDENCE FROM THE TAMAR AND MACQUARIE GRABENS, NORTHERN TASMANIA
}

\author{
by Mike Macphail and Greg Jordan
}

(with one plate)

\begin{abstract}
Macphail, M.K. \& Jordan, G.J. 2015 (18:xii)Tropical palms and arums at near-polar latitudes: fossil pollen evidence from the Tamar and Macquarie grabens, northern Tasmania. Papers and Proceedings of the Royal Society of Tasmania 149: 23-28.

https://doi.org/10.26749/rstpp.149.23 ISSN 0080-4703. Department of Archaeology \& Natural History, College of Asia \& the Pacific, Australian National University, Canberra, ACT $0200\left(\mathrm{MM}^{*}\right)$; School of Plant Sciences, University of Tasmania, Sandy Bay, Tasmania 7005 (GJ).*Author for correspondence: Email mike.macphail@anu.edu.au
\end{abstract}

We illustrate and discuss fossil pollen evidence for two mostly tropical extant plant families in the Tamar Valley, north of Launceston, northern Tasmania, and the Macquarie Harbour Graben on the west coast of Tasmania. These are palms (Arecaceae) producing disulcate pollen (Dicolpopollis spp.) and an incompletely zonisulcate pollen (Proxapertites cf. operculatus) identified as a fossil arum (Araceae). Both fossil pollen types add to the growing body of evidence that warm to hot conditions allowed tropical monocots belonging to these two families to grow at high palaeolatitudes $\left(\mathrm{c} .65^{\circ} \mathrm{S}\right)$ during the Late Paleocene and/or Early Eocene in Tasmania and even closer to the pole $\left(\right.$ c. $\left.70^{\circ} \mathrm{S}\right)$ during the Late Cretaceous in central and southern mainland Australia.

Key Words: Fossil palms, arums, Arecaceae, Araceae, Dicolpopollis, Proxapertites, Late Cretaceous, Late Paleocene, Early Eocene, Tasmania, southern and central Australia.

\section{INTRODUCTION}

Palms (Arecaceae) and to a lesser extent arums (Araceae) are archetypal indicators of extant tropical environments, and fossil occurrences of palm pollen in particular have been used as evidence for warm to hot conditions at high palaeolatitudes in both hemispheres in the past (see Mai 2000). A key taxon is the tropical mangrove palm $N y p a$, a genus that achieved a nearly worldwide distribution during the Eocene (references in Gee 2001), consistent with episodes of methane-induced global warming (hyperthermals) during the Early Eocene (see Zachos et al. 2008). Nypa fruits, fronds and/or pollen (fossil equivalent Spinizonocolpitesprominatus) have been found in Paleocene to Early Eocene sediments in the continental margin basins around Australia, including in the Early Eocene Macquarie Harbour Beds at Strahan on Tasmania's West Coast (references in Pole \& Macphail 1996, Dowe 2010). The latter are part of a growing body of evidence for near-tropical mean air temperatures (MAT) within the partially occluded gulf separating Australia and Antarctica at a palaeolatitude of c. $65^{\circ} \mathrm{S}$ (Carpenter $e t$ al. 2012). Conditions at this latitude include several months of winter darkness and, at present, subzero MATs.

In this Extended Abstract, we illustrate and discuss two fossil pollen types (Dicolpopollis, Proxapertites cf operculatus) preserved in Late Paleocene and Early Eocene sediments, respectively, infilling the Tamar Graben north of Launceston and Macquarie Harbour Graben near Strahan. These fossil pollen have close morphological affinities to modern pollen produced by tropical members of the Arecaceae and Araceae families (see Hesse et al. 2001, Hesse \& Zetter 2005, 2007). Unlike $N y p a$, corresponding macrofossils have not been found. The specimens are part of a plexus of fossil arecoid and aroid morphotypes (see Table 1 in Harley \&
Baker 2001) found in marine and terrestrial sediments in Australia that range in time from the Campanian to the Plio-Pleistocene and in space from Tasmania to the North-West Shelf. Late Cretaceous morphotypes are not described in this paper but examples are illustrated in pl. 1, e.g., Maastrichtian specimens of Proxapertites of operculatus and Arecipites Wodehouse 1933 emend Nichols et al. 1973 from the Bundey Basin in Central Australia, and Cenomanian specimens referred to Mauritiidites van Hoeken-Klinkenberg 1964 and Nupharipollis Krutzsch 1970 from the Bight Basin off the coast of South Australia. Two palm (Archontophoenix, Livistona) and two arum (Alocasia, Gymnostachys) genera extend as far south as c. $33-35^{\circ} \mathrm{S}$ along the central and south coasts of New South Wales but other genera are mostly confined to Queensland and the Northern Territory (see Hnatiuk 1980).

\section{LOCATIONS}

The geological setting and Cenozoic evolution of the N-S orientated Tamar Graben, now partly occupied by the Tamar Estuary in northern Tasmania, and Macquarie Harbour Graben near Strahan on the West Coast of Tasmania have been reviewed by Carpenter et al. (2012) and Forsyth et al. (2014). The fossil arecoid/aroid pollen morphotypes were recovered from (a) a sequence of carbonaceous silts at 179.20-291.8 m depth in the Bell Bay BH-1 corehole $(487717.6167 \mathrm{mE}$ 5446018.027mN MGA: RL 39.5 m) drilled at Bell Bay near the mouth of the Tamar River (Macphail 2014a) and (b) carbonaceous mudstones at $184.1 \mathrm{~m}$ depth in Strahan STR-BH1 (358300mE, 5335100 mN MGA RL 38.2 m) drilled behind Ocean Beach at Strahan. Both coreholes were drilled by the Tasmanian Department of Mines (now 


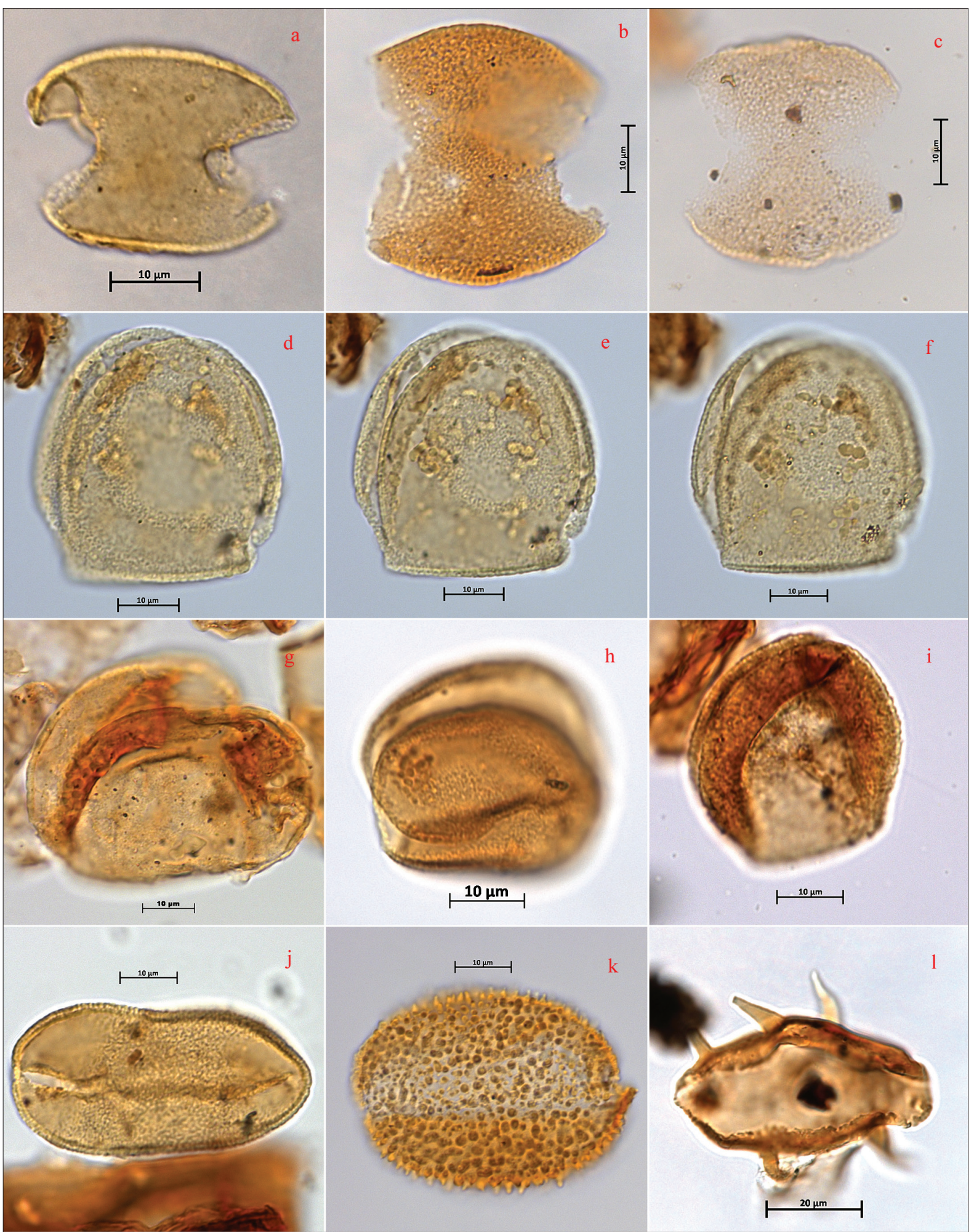

PLATE 1 - a: Dicolpopollis sp. Bell Bay BH-1 287 m, Tamar Graben, northern Tasmania. Specimen in polar view (Late Paleocene).

b: Dicolpopollis sp. Geoscience Australia dredge sample GAB SS012007/21DR13 B5.1, offshore Bight Basin, southern Australia. Specimen in polar view (Cenomanian). c: Dicolpopollis sp. Geoscience Australia dredge sample SS012007/22DR14 D3, offshore Bight Basin, southern Australia. Specimen in polar view (Cenomanian). d: Proxapertites cf operculatus Bell Bay BH-1 179.30-179.33 m, Tamar Graben, northern Tasmania. Specimen in equatorial view (Early Eocene). e: Proxapertites cf operculatus Bell Bay BH-1 179.30-179.33 m, Tamar Graben, northern Tasmania. Specimen in equatorial view (Early Eocene). f: Proxapertites cf operculatus Bell Bay BH-1 179.30-179.33 m, Tamar Graben, northern Tasmania. Specimen in equatorial view (Early Eocene). g: Proxapertites cf operculatus Strahan STR BH-1 184.1 m, Macquarie Harbour Graben, western Tasmania. Specimen in equatorial view (Early Eocene). h: Proxapertites cf operculatus Santa Teresa ST4 73.25-73.28 m, Santa Teresa Basin, Central Australia. Specimen in equatorial view (Early Eocene). i: Proxapertites cf operculatus HUC-11 102.45-102.54 m, Bundey Basin, Central Australia. Specimen in equatorial view (Late Maastrichtian). j: Arecipites sp. HUC-11 102.45-102.54 m, Bundey Basin, Central Australia. Specimen in proximal polar view (Late Campanian-Early Maastrichtian). k: Mauritiidites sp. HUC-11 96.00-96.03 m, Bundey Basin, Central Australia. Specimen in proximal polar view (Maastrichtian).I: Nupharipollis sp. Geoscience Australia dredge sample SS012007/28DR20 A5.1, offshore Bight Basin, southern Australia. Specimen in proximal polar view (Cenomanian). 
Mineral Resources Tasmania) in the early 1980s. Bell Bay $\mathrm{BH}-1$ intersected a discontinuous sequence of conglomerates, sands and silts deposited in a series of freshwater fens during the Oligocene, Early Eocene and Late Paleocene (Late Thanetian). The Cenozoic infill (Launceston Beds) includes a number of thin cemented ferruginous intervals (ironstones/ ferricretes) and unconformably overlies Jurassic dolerites at $293.6 \mathrm{~m}$ depth. Sediments deposited in the Macquarie Harbour Graben underlie Late Quaternary sand dunes at Ocean Beach and outcrop in sea cliffs southwards along the eastern shoreline of Macquarie Harbour. Subaeriallyexposed marginal marine strata demonstrate the infill (Macquarie Harbour Formation) has undergone down-tobasin (en-echelon) faulting during separation of Australia and Antarctica in the Late Cretaceous and Early Paleogene, followed by uplift, due to tilting of the Australian continent during the Neogene and Quaternary (see Pole 1998, Corbett 2003, Quigley et al. 2010). Strahan STR BH-1 intersected a c. $165 \mathrm{~m}$ thick interval of middle to late Early Eocene sediments (Macquarie Harbour Formation) overlying a dolerite conglomerate at c. $364 \mathrm{~m}$ depth. Palynostratigraphic analysis of weakly-lithified organic-rich clays, sands and lignites show the interval between 184.1-289.0 m depth was deposited in freshwater swamps whilst abundant Spinizonocolpites prominatus and marine dinoflagellates, confirm the interval between 346.5 and $349.0 \mathrm{~m}$ depth accumulated in a tidal estuarine environment (Macphail \& Partridge 2012).

\section{AGE CONTROL}

The age control is based on the time distribution of fossil pollen and spore species (morphospecies) in the Bass, Gippsland and Murray basins (Macphail 1999, Partridge 1999, 2006,), with additional local control provided by sites elsewhere in Tasmania to Central Australia (see Macphail 1997, Macphail et al. 2014). Basalts at and above $19.6 \mathrm{~m}$ in Bell Bay BH-1 have not been independently dated. Marine dinoflagellates provide independent age control for Strahan BH-1 (see Macphail \& Partridge 2012, Carpenter et al. 2012).

\section{FOSSIL POLLEN}

The fossil arecoid and aroid pollen types are illustrated in $\mathrm{pl}$. 1. We emphasise that the Tamar and Macquarie Harbour Graben specimens are not formally described in this paper because of (a) the paucity of Dicolpopollis specimens and (b) the strong probability the Tamar and Macquarie Harbour specimens of Proxapertites can be accommodated in the formally described morphospecies P. operculatus Van der Hammen 1956. Pollen morphological terms follow Harley \& Baker (2001) and Punt et al. (2007).

\section{A. Dicolpopollis Pflanzl 1956 emend Ediger et al. 1990}

Fossil pollen referred to the morphogenus Dicolpopollis are distinguished by two sulci that usually are parallel to each other and which sometimes converge or even touch on the short side. The outline (amb) is symmetric ellipsoid ("bobbinshaped": Harley \& Baker 2001) in polar view and irregularly elliptical to trapezoidal in equatorial view. The pollen wall (exine) is two-layered, relatively thick and ornamented with vermiculate, rugulate or reticulate sculptural elements. Individual grains (monads) are usually flattened along the meridional plane and the aperture, a sulcus, is usually seen as notches on the equator in the equatorially flattened grains. The size range was not specified in the formal description of the morphogenus (see Card 4230 in Jansonius \& Hills 1985).

Tamar Graben: A disulcate pollen morphotype recorded $287.0 \mathrm{~m}$ (Late Thanetian) in Bell Bay BH-1 (pl. 1a) conforms closely to the generic description although the specimen, orientated in polar view, is too poorly preserved to determine if the ornamentation is psilate, reticulate, verrucate or granulate.

Comment: Calibration points for molecular dating of the genus level palm phylogeny indicate that extant palm lineages initially diversified in a tropical rainforestlike biome at about $100 \mathrm{Ma}$ (Late Albian) at northern latitudes in Laurasia (Couvreur \& Baker 2015). The earliest unequivocal palm macrofossils are early Late Cretaceous (see Harley 2006). According to the website maintained by the Russian Academy of Science (palaeobotany.ru/index. php), some 25 pollen fossil species (morphospecies) of Dicolpopollis have been formally described, which range in age from Middle Albian to Pliocene. These equatorially disulcate grains are considered to be fossil members of the subfamily Calamoideae, with particular morphospecies referred to extant genera (Harley \& Baker 2001). For example, microreticulate and foveolate morphotypes assigned to Dicolpopollis kockelii Pflanzl 1956 ex Potonié 1966 and D. metroxylonoides Khan 1976 are considered to be fossil representatives of the rattan palm Calamus and sago palm Metroxylon, respectively (see Harley \& Baker 2001). For the same reason, significant relative abundances are considered to be reliable evidence for moist tropical climates, e.g., Lelono (2012). Fossil Dicolpopollis specimens in Australia have not been consistently recorded but illustrated records include (a) a number of described and undescribed Dicolpopollis spp. from Cenomanian sediments on Bathurst Island, north of Darwin in the Northern Territory (pl. 32 figs 8-10 in Norvick \& Burger 1976), (b) the microreticulate species $D$. bungonensis from Middle Eocene deposits on the Southeast Highland of New South Wales (fig. 5 A-D, G-I in Truswell \& Owen 1988) and (c) specimens compared to D. metroxylonoides in Early Eocene to Late? Miocene sediments in the Murray-Darling Basin (fig. 7G in Truswell et al. 1985, pl. 4 fig. 8 in Macphail 1999). The earliest records of the morphogenus we know of in southern Australia occur in Cenomanian (Hoegisporis uniforma Zone) sediments in the Bight Basin (Appendix 3.1 in Totterdell \& Mitchell 2009). One of the fossil morphotypes (pl. 1b-c) resembles pollen produced by the 
tropical Asian to west Malaysian rattan palm Plectocomia elongata (cf. figs 29-31 in Harley \& Baker 2001).

\section{B. Proxapertites Van der Hammen 1956 emend Singh 1975}

Fossil pollen referred to the morphogenus Proxapertites are circular to subcircular in shape, and zonisulcate with a tectate exine. Since the sulcus is more or less parallel to margin, the pollen grain often breaks into two approximately equal halves. Ornamentation varies from none (psilate) to granulose, punctate, microfoveolate or reticulate (see Card 4322 in Jansonius \& Hills 1985).

The type species P. operculatus Van der Hammen 1956 is described as radially symmetrical but slightly anisopolar since the grains are separated by a continuous equatorial colpus into two slightly unequal parts; oblate and rounded angular to oval in polar view; colpus ectexinous, somewhat irregularly bordered by a narrow indistinct margin of thinning exine, columellae indistinct , $1 \mu \mathrm{m}$ long,$<0.5 \mu \mathrm{m}$ thick, covered by a $<1 \mu \mathrm{m}$ thick finely reticulate-perforate tectum, lumina $1 \mu \mathrm{m}$ wide, smaller along margins of colpus, muri $0.5 \mu \mathrm{m}$ wide, $<1 \mu \mathrm{m}$ high. $36-61 \mu \mathrm{m}$ and variable in shape (see Gemeraad et al. 1968). Individual grains range in size from $20-70 \mu \mathrm{m}$ in height and $25-50 \mu \mathrm{m}$ in length. The clam-shell or hamburger-shaped amb view distinguishes Proxapertites operculatus from the ellipsoidal to trapezoidal-shaped foveolate to reticulate morphospecies assigned to Longapertites van Hoeken Klinkenberg 1964 (see Jansonius \& Hills 1985: Card 4282; pl. 5 figs 13-6 in Schrank 1994).

Tamar Graben: Pollen grains, which appear to be identical to illustrated specimens of Proxapertites operculatus, occur in low numbers (relative abundance 2\%) at 179.30-179-33 m (midlate Early Eocene) in Bell Bay BH-1 (pl. 1d-f, Macphail 2014a). For example, the specimens are zonisulcate with an irregular very fine reticulate sculpture. However, the Bell Bay BH-1 specimens differ from the formal diagnosis of $P$. operculatus in that they are incompletely zonisulcate and the columellae along the sulcal margins are distinctly visible. Whether these differences are sufficient to exclude the Tamar Graben population from P. operculatus is unclear but this seems unlikely given the broad range of sculptural morphotypes accommodated within this morphospecies and very wide distribution of fossil records of the morphospecies in geologic time and space (see Muller 1968, Jamarillo \& Dilcher 2001, Hesse \& Zetter 2007, Lelono 2007).

Macquarie Harbour: Records of Proxapertites cf. operculatus in the Macquarie Harbour Graben consist of several grains recovered from a middle Early Eocene claystone with coalified macrofossil remains at $184.1 \mathrm{~m}$ depth in Strahan BH-1 (pl. 1g, Macphail 2014b). Despite the distorted state of preservation, these grains possess the same key morphological characters as the Tamar Graben specimens, viz. an irregular very fine reticulate sculpture and the presence of granules along the margin of the zonisulcus.

Comment: Harley \& Baker (2001) and Harley (2006) interpret Proxapertites operculatus (and Longapertites) as a fossil arecoid whose nearest living relative (NLR) is the tall palm genus Areca, found in humid tropical forests from
China and India through Malesia to tropical Australia. The arecoid affinity has been strongly challenged by Hesse et al. (2001), Zetter et al. (2001) and Hesse \& Zetter (2005, 2007) who conclude the morphospecies is most probably an ancestral member of Araceae subfamily Monsteroideae and/or subfamily Zamioculcadoideae, comparable to pollen of the modern genera Monstera, Gonatopus and Zamioculcas. Unlike Areca, these genera range in stature from herbs growing from tubers and rhizomes to evergreen vines, have modern distributions centred in eastern Africa and the tropical Americas, and include drought-tolerant and deciduous species. Monosulcate pollen of probable monocotyledonous origin first appear in the Early Cretaceous (see Friis et al. 2010) but, as far as is known, the only previously illustrated Proxapertites specimens (incorrectly referred to Longapertites) in Australia come from Early Eocene lacustrine sediments in the Cenozoic Santa Teresa Basin in Central Australia (figs 4-5 in Macphail 1997).

\section{DISCUSSION}

On present indications, the Arecaceae and Araceae evolved during the Early Cretaceous and may have achieved a worldwide distribution during the Late Cretaceous (Hesse \&Zetter 2007, Baker \& Couvreur 2013, Couvreur \& Baker 2015). The fossil pollen record for individual morphospecies, however, is more varied in time and space. For example, fossil pollen assigned to Proxapertites operculatus have a pantropical (predominantly Gondwanan) distribution, with Cretaceous records including the Barremian-Aptian in Portugal, (see fig. 3 in Friis et al. 1994) and the Maastrichtian in Africa and the Caribbean. During the Cenozoic, the morphospecies is at its most frequent in the Paleocene to Early Eocene in northern South America, but is restricted to the Eocene in Europe.

When palms and arums first reached Australia is less clear because of the patchy nature of the fossil record in the epicontinental basins, all of which have been subject to widespread erosion and/or deep weathering, and in the continental margin basins, especially those on northwestern and northern margins, which have suffered sediment starvation during and since the Late Cretaceous. Assuming Arecipites, Dicolpopollis, Mauritiidites and Nupharipollis specimens from the Central Australian and the Bight Basins represent arecoid lineages, then palms were present in southern Australia during the Cenomanian, a period when this region (Great Australian Bight) was at a palaeolatitude of c. $70^{\circ} \mathrm{S}$ (see Veevers et al. 1991). By CampanianMaastrichtian time, potential fossil arecoid pollen also include a range of undescribed psilate, baculate, gemmate and verrucate monosulcate morphotypes preserved in independently-dated marine sediments in the offshore Bonaparte Basin, west of Darwin, and offshore Browse Basin on the west coast of Western Australia (Macphail 2007). The earliest known specimen of Proxapertites is a poorly preserved specimen in a Maastrichtian fen sediment intersected at 102.45-102.54 m depth in the HUC-11 
corehole drilled by the Northern Territory Geological Survey in the Bundey Basin, Central Australia (pl. 1i).

In contrast, the earliest known record of fossil Nypa pollen (Spinizonocolpites prominatus) comes from independentlydated Paleocene sediments in the Carnarvon Basin off the central west coast of Western Australia (Macphail 2007). Both Spinizonocolpites and Proxapertites appear to reach their maximum abundance during one or more of the Early Eocene hyperthermals (see Zachos et al. 2008), albeit in different settings. For example Spinizonocolpites prominatus has been restricted to paralic environments in the continental margin basins around Australia (see Partridge 1976, Pole \& Macphail 1996) whilst Cenozoic populations of Proxapertites cf. operculatus have been recorded only in fluvio-lacustrine deposits in Central Australia and northern and western Tasmania. Dicolpopollis spp. are more widely recorded in marine and non-marine facies but, except for a Middle Eocene site on the Southern Highlands of New South Wales (Truswell \& Owen 1988), only occur in trace numbers.

Although these fossil pollen records are an unreliable basis for tracing migration pathways across Australia, our data suggest palms were well-established around the continental margins of Australia during the Late Cretaceous and thereafter became established inland when and where regional conditions were suitable during the Paleogene. For example, Spinizonocolpites prominatus became extinct in southeastern Australia in the relatively cool early Middle Eocene (Partridge 1999, 2006) although Nypa fruticans populations retain a toehold on the Coburg Peninsula near Darwin in Tropical northern Australia. Nevertheless our finding that Late Cretaceous arecoids were tolerant of seasonally cool climates is not that surprising given that even now one species, Rhopalostylis sapida, ranges as far

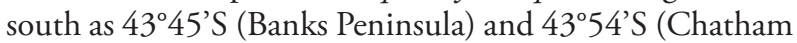
Islands) in New Zealand and another species, Livistona mariae, survives in the geographic centre of the arid zone in Australia (Finke Gorge National Park) at $24^{\circ} 12^{\prime} \mathrm{S}$, c. $138 \mathrm{~km}$ west of Alice Springs. The presence of Araceae at high palaeolatitudes is more surprising since $90 \%$ of genera and c. $95 \%$ of species are restricted to the tropics in South America and South East Asia. The importance of the Tamar Graben records therefore is not that palms and arums were present in Australia during the Paleogene but the apparent rapidity with which the Araceae (and Nypa) were able to migrate southwards to near-polar latitudes at a time (Early Eocene) when the continent was separated from Antarctica except for the narrow rift valley complex linking Tasmania to East Antarctica via the South Tasman Rise. Whether the arecoids and aroids reached Australia via Antarctica or from the north is unknown.

NOTE ADDED IN PROOF: Since this Extended Abstract was prepared, significant numbers of Proxapertites cf operculatus [ $4 \%$ of total dryland pollen count] have been recovered from lignite at $84-87 \mathrm{~m}$ depth in the water drillhole NTGS Ayers Rock RN 10598. The presence of Stereisporites maastrichtiensis, Proteacidites amolosexinus and Tricolpites lilliei, confirm an Upper Forcipites longus Zone Equivalent age for this interval and demonstrate a population of aroids (Araceae) was growing along a palaeovalley near Uluru in central Australia during the Late Maastrichtian.

\section{REFERENCES}

Baker, W.J. \& Couvreur, T.L.P. 2013: Global biogeography and diversification of palms sheds light on the evolution of tropical lineages. II. Diversification history and origin of regional assemblages. Journal of Biogeography 40: 286-298.

Carpenter, R.J., Jordan, J., Macphail, M.K. \& Hill, R.S. 2012: Near tropical Early Eocene terrestrial temperatures at the Austro-Antarctic margin. Geology 40: 267-270.

Corbett, K. 2003: A review of geology and exploration in Macquarie Harbour-Elliott Bay area, South West Tasmania: Tasmanian Geological Survey Record 2003/04: 1-31.

Couvreur, T.P.L. \& Baker, W.J. 2015: Tropical rainforest evolution: palms as a model group. BMC Biology 11: Corbett, K.D., Quilty, P.G. \& Calver, C.R. (eds.) 48 (doi: 10.1186/17417007-11-48)

Dowe, J.L. 2010: Australian Palms: Biogeography, Ecology and Systematics. CSIRO Publishing, Melbourne.

Friis, E.M., Pedersen, K.R. \& Crane, P.R. 1994: Araceae in the Early Cretaceous of Portugal: Evidence on the emergence of monocotyledons. Proceedings of the National Academy of Science USA. 101: 16565-16570.

Friis, E.M., Pedersen, K.R. \& Crane, P.R. 2010: Diversity in obscurity: fossil flowers and the early history of angiosperms. Philosophical Transactions of the Royal Society B365: 369-382.

Forsyth, S.M., Quilty, P.G. \& Calver, C.R. 2014: Cenozoic onshore basins and landscape evolution. In: Corbett, K.D., Quilty, P.G. \& Calver, C.R. (eds): Geological Evolution of Tasmania, pp. 437-450. Geological Society of Australia Special Publication 24, Geological Society of Australia (Tasmania Division).

Gee, C.T. 2001: The mangrove palm Nypa in the geologic past of the New World. Wetlands Ecology and Management 9: $181-194$.

Gemeraad, J.M., Hopping, C.A. \& Muller, J. 1968: Tertiary sediments from tropical areas. Review of Palaeobotany and Palynology 6:189-348.

Harley, M.M. 2006. A summary of fossil records for Arecaceae. Botanical Journal of the Linnaean Society 151: 39-67.

Harley, M.M. \& Baker, W.J. 2001: Pollen aperture morphology in Arecaceae: application within phylogenetic analyses, and a summary of the fossil record of palm-like pollen. Grana 40: 45-77.

Hesse, M. \& Zetter, R. 2005: Ultrastructure and diversity of recent and fossil zona-aperturate pollen grains. Plant Systematics and Evolution 255: 145-176.

Hesse, M. \& Zetter, R. 2007: The fossil pollen record of Araceae. Plant Systematics and Evolution 263: 93-115.

Hesse, M., Bogner, J., Halbritter, H. \& Weber, M. 2001: Palynology of the perigoniate Aroideae: Zamioculcas, Gonatopus and Stylochaeton (Araceae). Grana 40: 26-34.

Hnatiuk, R.J. 1980: Census of Australian Vascular Plants. Australian Flora and Fauna Series 11: 1-680. Australian Government Printing Service, Canberra: 650 pp.

Jaramillo, C.A. \& Dilcher, D.L. 2001: Middle Paleogene palynology of Central Columbia, South America: a study of pollen and spores from tropical latitudes. Palaeontographica Abt B 258: 87-213.

Jansonius, J. \& Hills, L.V. 1985: Genera Files of Fossil Spores Supplement. Special Publication, Department of Geology, University of Calgary, Canada.

Lelono, E. B. 2007: Gondwanan palynomorphs from the Paleogene 
sediments of east Java: ?The evidence of earlier arrival. LEMIGAS Scientific Contributions 30: 1-12.

Lelono, E.B. 2012: Oligocene palynology of on-shore West Java. Scientific Contributions Oil \& Gas 35: 67-82.

Macphail, M.K. 1997: Palynostratigraphy of Late Cretaceous to Tertiary Basins in the Alice Springs District, Northern Territory. AGSO Record 1997/13: 1-27.

Macphail, M.K. 1999: Palynostratigraphy of the Murray Basin, inland southeast Australia. Palynology 23: 199-242.

Macphail, M.K. 2007: Australian Palaeoclimates Cretaceous to Tertiary. A review of palaeobotanical and related evidence to the year 2000. CRC-LEME Open File Report 151 (Special Volume ISBN 192103975 2): 279 pp.

Macphail, M.K. 2014a: The Tamar Graben revisited: palynostratigraphic dating of new samples from the Bell Bay-1, Englewood-1 and Rowella-1 coreholes, northern Tasmania. Report prepared for Associate Professor G.J. Jordan, University of Tasmania (24 September).

Macphail, M.K. 2014b: Preliminary palynostratigraphic age determinations on core from Strahan BH-1, Macquarie Harbour, western Tasmania. Tasmanian Geological Survey Record 2013/08: 1-17.

Macphail, M.K. \& Partridge, A.D. 2012: First fossil record of Auriculiidites Elsik 1964 in Australia. Alcheringa 36: 283-286.

Macphail, M.K., Hill, R.S., Partridge, A.D. \& Jordan, G.J. 2014: Geo-botany of the Cretaceous to Neogene. In: Corbett, K.D., Quilty, P.G. \& Calver, C.R. (eds): Geological Evolution of Tasmania, pp. 495-507. Geological Society of Australia Special Publication 24, Geological Society of Australia (Tasmania Division).

Mai, D.H. 2000: Palm trees in the past - paleoclimatological and paleoecological indicators, GFF: 122: 1, 97-98 (doi: 10.1080/11035890001221097).

Muller, J. 1968. Palynology of the Pedawan and Plateau Sandstone Formations (Cretaceous-Eocene) in Sarawak, Malaysia. Micropaleontology 14: 1-37.

Norvick, M. \& Burger, D. 1976: Palynology of the Cenomanian of Bathurst Island, Northern Territory, Australia. Bureau of Mineral Resources Bulletin 151: 1-169.

Partridge, A.D. 1976: The geological expression of eustacy in the Early Tertiary of the Gippsland Basin, Australia. APEA Journal 16: 73-79.

Partridge, A.D. 1999: Late Cretaceous to Tertiary Geological
Evolution of the Gippsland Basin, Victoria. 2 Volumes. Unpublished $\mathrm{PhD}$ thesis, Latrobe University, Melbourne: 439 pp.

Partridge, A.D. 2006: Late Cretaceous-Cenozoic palynology zonations, Gippsland Basin. In: Monteil, E. (coordinator) Australian Mesozoic and Cenozoic Palynology Zonations - updated to the 2004 Geologic Time Scale. Geoscience Australia Record 2006/23 (ISBN I 92123605 1).

Pole, M.S. 1998: Early Eocene estuary at Strahan, Tasmania. Australian Journal of Earth Sciences 45: 979-985.

Pole, M. \& Macphail, M.K. 1996: Eocene Nypa from Regatta Point, Tasmania. Review of Palaeobotany and Palynology 92: 55-67.

Punt, W., Hoen, P.P., Blackmore, S, Nilsson, S. \& Le Thomas, A. 2007: Glossary of pollen and spore terminology. Review of Palaeobotany and Palynology 143:1-81.

Quigley, M.C., Clark, D. \& Sandiford, M. 2010: Tectonic geomorphology of Australia. In: Bishop, P., Pillans, B. (eds) Australian Landscapes. Geological Society, London, Special Publications, 346: 243-265.

Schrank, E. 1994: Palynology of the Yesomma Formation in northern Somalia: a study of pollen, spores and associated phytoplankton from the Late Cretaceous Palmae Province. Palaeontographica Abt. B 231: 63-112.

Totterdell, J. \& Mitchell, C. 2009: Bight Basin geological sampling and seepage survey. Geoscience Australia Record 2009/24: 1-128.

Truswell, E.M. \& Owen, J.A. 1988: Eocene pollen from Bungonia, New South Wales. Memoir Association of Australasian Palaeontologists 5: 259-284.

Truswell, E.M., Sluiter, I.R. \& Harris, W.K. 1985: Palynology of the Oligocene-Miocene sequence in the Oakvale-1 corehole, western Murray Basin, South Australia. BMR Journal of Australian Geology and Geophysics 9: 267-295.

Veevers, J.J., Powell, C. McA. \& Roots, S.R. 1991: Review of seafloor spreading around Australia. 1. Synthesis of the patterns of spreading. Australian Journal of Earth Sciences 38: 373-389.

Zachos, J.C., Dickens, G.R., \& Zeebe, R.E. 2008: An early Cenozoic perspective on greenhouse warming and carboncycle dynamics. Nature 451: 279-283.

Zetter, R., Hesse, M. \& Frosch-Radivo, A. 2001: Early Eocene zona-aperturate pollen grains of the Proxapertites type with affinity to Araceae. Review. Palaeobotany and Palynology 117: 267-279.

(accepted 4 November 2015) 